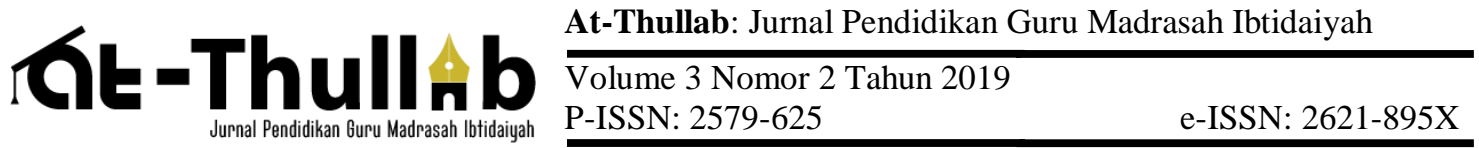

\section{UPAYA MENINGKATKAN HASIL BELAJAR PEMBELAJARAN PASSING BAWAH BOLA VOLY MELALUI METODE BERMAIN SISWA KELAS V}

\author{
Muh. Eko Tirto Noviyantoro \\ SDN Pandan 1 Omben \\ e-mail: ekotirto@gmail.com
}

\begin{abstract}
This research aims to improve learning outcomes under passing on volleyball game using the play method. This research using the Classroom Action Research (PTK) approach. The subject of this research of class $V$ of elementary school at SDN Pandan 1 Omben. This research was conducted with six meetings consisting of two cycle, every cycle 3 times meeting. The first cycle that is realized through action according to the plan and learning method, the result is $74 \%$ of students graduate. In the second cycle which is realized through reflection action results from cycle 1 , the result is the average value of students in underpass learning increases to $92 \%$ of students graduating. Based on the results of the study can be concluded that passing under learning using the play method can improve student learning outcomes in class $V$ at SDN Pandan 1 Omben.
\end{abstract}

Keywords: learning outcome, volleyball, play method

\section{A. Pendahuluan}

Pendidikan Jasmani merupakan media untuk mendorong perkembangan keterampilan motorik, kemampuan fisik, pengetahuan dan penalaran, penghayatan nilainilai (sikap mental emosional, spiritual, sosial) serta pembiasaan pola hidup sehat yang bermuara untuk merangsang pertumbuhan dan perkembangan yang seimbang. Menurut Hanif \& Sugito (2015) pendidikan jasmani merupakan bagian yang tidak dapat dipisahkan dari kehidupan manusia, melalui pendidikan jasmani manusia dapat belajar lebih banyak hal yang berhubungan dengan afektif, kongnitif, dan psikomotor yang merupakan bekal manusia untuk mencapai tujuan hidup.

Pendidikan jasmani selalu tidak lepas dari kegiatan aktivitas. Salah satunya aktivitas bermain. Bermain merupakan salah satu aktivitas jasmani yang sangat disukai anak dalam kehidupan sehari-hari sehingga dapat digunakan sebagai salah satu sarana pendidikan jasmani di sekolah. Bermain bagi anak merupakan kegiatan harian yang sangat menarik dan menyenangkan untuk dilakukan sepanjang waktu. Salah satu kegiatan permainan dalam pembelajaran pendidikan jasmani adalah permainan bola voly. Namun bagi sebagian siswa kelas V SDN Pandan 1 Omben permainan bola voly merupakan permainan yang cukup sulit dan menakutkan karena dalam permainan ini terdapat kegiatan memukul, menahan, dan mendorong bola yang cukup keras dengan menggunakan kedua lengan yang dapat menimbulkan rasa sakit pada lengannya. 
Menurut Viera (2000) bola voli merupakan jenis permainan olahraga beregu yang masing-masing regu dimainkan oleh dua tim,dimana tiap tim beranggotakan enam orang dalam lapangan berukuran 30 kaki persegi (9 meter persegi) bagi setiap tim dipisahkan oleh net atau jaring. Pada dasarnya permainan bola voli adalah permainan beregu, selain itu juga harus dapat menguasai atau mengetahui teknik-teknik permainan bola voli. Menurut Barth dan Heuchert (2007) tindakan yang paling penting dan harus dikuasai dalam permainan bola voli adalah diantaranya : (a) Receiving, (b) Passing, (c) Attacking, (d) Blocking, (e) Back Row Defense, (f) Serving.

Selama ini pembelajaran jasmani di SD Negeri Pandan 1 Omben dalam proses pembelajaran passing bawah, siswa masih mengalami kesulitan dalam penguasaan teknik passing bawah. Pada saat proses belajar mengajar passing bawah kebanyakan siswa kelas IV mengeluh tangan sakit dan merasa bosan dengan metode pembelajaran yang ada juga siswa kesulitan dalam mengoper bola tepat sasaran yang di inginkan. Hal ini di karenakan pada saat melakukuan passing bahwa tidak sesuai dengan teknik passing bawah dengan benar. Oleh karena itu, agar siswa memahami materi dengan benar, guru dituntut harus kreatif dalam memberikan materi kepada siswa, salah satunya melalui metode atau pendekatan pembelajaran yang sesuai dengan perkembangan atau karakteristik siswa yaitu melalui metode bermain, sehingga diharapkan siswa akan lebih bergerak aktif, memiliki kemauan untuk belajar gerakan baru, lebih berani, dan lebih percaya diri dalam melakukan setiap gerakan yang ada dalam permainan bola voli.

Pembelajaran yang dirancang dalam bentuk permainan bertujuan untuk memenuhi hasrat gerak siswa yang di dalamnya terdapat unsur belajar, terlebih dalam mengikuti aktivitas belajar banyak hal yang dirasakan oleh para siswa mulai dari perubahan situasi lingkungan, teman baru, suasana pergaulan dalam konteks bermain yang menyenangkan, hingga situasi kedisiplinan dan tanggung jawab yang kadang dirasakan begitu mengikat atau dengan kata lain bermain sambil belajar (Pambudi, P. S., \& Pramudana, 2016).

Menurut Tedjasaputra (2001) Melalui bermain siswa memahami kaitan antara dirinya dan lingkungan sosialnya, belajar bergaul dan memahami aturan ataupun tata cara pergaulan. Selain itu, kegiatan bermain berkaitan erat dengan perkembangan kognitif anak. Berbagai cara dalam pelaksanaan pembelajaran harus dikemas menjadi situasi permainan yang menyenangkan, serta peraturan permainan yang disederhanakan atau dimodifikasi harus diterapkan, sehingga para siswa akan merasa senang dalam menjalankan proses belajarnya. Dengan begitu diharapkan hasil belajar siswa akan menigkat dan motivasi siswa dalam proses belajarnya akan semakin bertambah, sehingga tujuan dari penelitan ini yaitu untuk meningkatkan hasil belajar passing bawah dengan menggunakan metode bermain dapat tercapai sesuai dengan target yang diinginkan. 


\section{B. Metode}

Penelitian ini merupakan Penelitian Tindakan Kelas (PTK). Pelaksanaan PTK dilaksanakan melalui beberapa tahapan antara lain (1) Perencanaan/Olanning, (2) Tindakan/Acting, (3) Pengamatan/Observing, (4) Refleksi/Reflecting, dan akan diadakan revisi perencanaan pada siklus ulang jika masih diperlukan. Subyek penelitian ini adalah siswa kelas V SDN Pandan 1 Omben, Kabupaten Sampang - Madura yang telah melaksanakan pembelajaran passing bawah dengan menggunakan metode bermain dan sudah melakukan tes hasil belajar passing bawah bola voli.

Instrumen yang digunakan dalam penelitian ini adalah dengan menggunakan tes hasil belajar passing bawah yang menekankan pada penilaian proses gerakan, dimulai dari sikap awal, sikap pada saat perkenaan dengan bola (pada saat eksekusi), dan sikap akhir pada saat bola telah dipukul. Masing-masing aspek tersebut akan menghasilkan skor $1,2,3$, dan 4 .

Tehnik pengumpulan data dalam penelitian ini menggunakan tes praktik, pengamatan observasi, dokumentasi. Teknik praktik digunakan untuk menilai hasil belajar passing bawah, tes ini digunakan untuk mendapatkan data kuantitatif berupa nilai yang menggambarkan hasil atau pencapaian siswa dalam melakukan tes tersebut. Observasi, digunakan untuk mengetahui hasil yang didapat siswa dan respon siswa terhadap proses pembelajaran permainan bola voli dengan menggunakan metode bermain. Data tersebut tercatat dan dipaparkan dalam catatan lapangan (dokumentasi). Dokumentasi, digunakan untuk mendeskripsikan kejadian-kejadian yang terjadi selama proses penelitian tindakan berlangsung.

Teknik analisis data yang digunakan adalah dengan cara mengumpulkan data yang didapat dari sumber penelitian. Setelah data terkumpul, maka selanjutnya data tersebut dianalisis berdasarkan dari hasil observasi yang dilakukan oleh kolaborator. Data tersebut kemudian ditulis dalam bentuk tabel untuk selanjutnya dideskripsikan dengan membandingkan antara hasil pencapaian yang didapat dengan indikator keberhasilan yang telah ditentukan.

\section{Hasil dan Pembahasan}

Proses penelitian diawali guru sebagai peneliti melakukan observasi terhadap proses pembelajaran passing bawah pada siswa kelas V SD Negeri Pandan 1 Kecamatan Omben Kabupaten Sampang, dalam observasi tersebut ditemukan bahwa masih banyak siswa yang belum mampu melakukan passing bawah dengan benar. Berikut data hasil tes awal yang diperoleh pada tahap pra siklus materi passing bawah bola voli: 
Tabel 1. Hasil Tes awal passing bawah bola voly

\begin{tabular}{ccc}
\hline No & Persentase & Kategori \\
\hline $\mathbf{1}$ & $22 \%$ & Sangat Kurang \\
\hline $\mathbf{2}$ & $34 \%$ & Kurang \\
\hline $\mathbf{3}$ & $26 \%$ & Cukup \\
\hline $\mathbf{4}$ & $10 \%$ & Baik \\
\hline $\mathbf{5}$ & $8 \%$ & Sangat Baik \\
\hline
\end{tabular}

Berdasarkan data pada Tabel 1 dapat diketahui bahwa sebanyak 56\% siswa belum mencapai target dari Kriteria Ketuntasan Minimal (KKM). KKM yang sudah ditentukan untuk mata pelajaran penjasorker adalah 70. Maka dari itu peneliti menyusun sebuah tindakan pembelajaran dengan menggunakan metode bermain untuk meningkatkan hasil belajar passing bawah siswa kelas V di SDN Pandan 1.

Pada Siklus I, pembelajaran passing bawah dengan menggunakan metode bermain sudah cukup memberikan semangat kepada siswa dalam melaksanakan proses belajarnya, sehingga siswa lebih antusias dalam mengikuti pembelajaran. Namun masih ada siswa yang belum mampu menunjukkan kemampuan passing bawah bola voly dengan klasisfikasi passing bawah individu, passing bawah dengan tembok, passing bawah dengan teman, dan passing bawah melewati net yang diberikan oleh guru. Sehingga guru mengambil langkah terhadap apa saja yang menjadi faktor penghambat pada siklus I, diantaranya tindakan yang akan diaplikasikan pada siklus II. Berikut hasil belajar passing bawah bola voly Siklus I

Tabel 2 Hasil Tes Passing Bawah Bola Voly Siklus I

\begin{tabular}{ccc}
\hline No & Persentase & Kategori \\
\hline $\mathbf{1}$ & $4 \%$ & Sangat Kurang \\
\hline $\mathbf{2}$ & $22 \%$ & Kurang \\
\hline $\mathbf{3}$ & $41 \%$ & Cukup \\
\hline $\mathbf{4}$ & $22 \%$ & Baik \\
\hline $\mathbf{5}$ & $11 \%$ & Sangat Baik \\
\hline
\end{tabular}

Hasil tersebut dirasakan masih kurang memuaskan bagi peneliti, karena belum memenuhi target atau kriteria keberhasilan yang sudah peneliti tetapkan sebelumnya, yaitu 80\% dari jumlah keseluruhan siswa harus lulus atau sudah memenuhi KKM. Maka dari itu, peneliti perlu menyusun kembali sebuah tindakan pada siklus berikutnya agar target atau kriteria keberhasilan pada penelitian ini dapat tercapai.

Proses kegiatan belajar mengajar mata pelajaran penjasorkes materi passing bawah bola voli pada siklus II, masih menggunakan metode bermain melalui permainan bola pantul. Siklus ini merupakan penyempurnaan dari kegiatan belajar mengajar selama 
siklus I. Tidak berbeda dengan siklus sebelumnya, pada siklus ini guru juga memberikan evaluasi pembelajaran terhadap siswa, kegiatan ini bertujuan untuk memperoleh data hasil belajar siswa setelah diberi tindakan. Berikut hasil yang diperoleh siswa pada siklus II

Tabel 3 Hasil Tes Passing Bawah Bola Voly Siklus II

\begin{tabular}{ccc}
\hline No & Persentase & Kategori \\
\hline $\mathbf{1}$ & $0 \%$ & Sangat Kurang \\
\hline $\mathbf{2}$ & $8 \%$ & Kurang \\
\hline $\mathbf{3}$ & $22 \%$ & Cukup \\
\hline $\mathbf{4}$ & $41 \%$ & Baik \\
\hline $\mathbf{5}$ & $29 \%$ & Sangat Baik \\
\hline
\end{tabular}

Berdasarkan data tersebut di atas dapat dilihat bahwa setelah diberikannya tindakan pada siklus II, hasil belajar passing bawah bola voli siswa meningkat. Hasil tersebut menunjukkan bahwa target atau kriteria keberhasilan yang sudah peneliti tetapkan sebelumnya sudah tercapai, yaitu $80 \%$ dari jumlah keseluruhan siswa harus lulus atau sudah memenuhi KKM. Maka dari itu dapat disimpulkan bahwa tindakan yang diberikan pada siklus II ini telah mencapai hasil yang baik. Dengan demikian penelitian tindakan kelas pada siklus II sudah dianggap cukup, karena hampir semua siswa kelas V telah mencapai KKM.

Peningkatan yang terjadi baik pada siklus I dan siklus II tak lepas dari penerapan metode permainan. Metode permainan merupakan suatu pendekatan dalam proses pembelajaran yang dikonsep dalam bentuk permainan dimana didalamnya dijelaskan mengenai teknik maupun taktik yang akan diberikan dengan menggunakan suatu permainan yang dimodifikasi. Dengan bermain hasrat siswa akan terpenehui namun, didalam permainan tersebut terkandung unsur pembelajaran. Permainan bertujuan untuk memenuhi hasrat gerak siswa yang didalamnya terdapat unsur belajar, terlebih dalam mengikuti aktivitas belajar banyak hal yang dirasakan oleh para siswa mulai dari perubahan situasi lingkungan, teman baru, suasana pergaulan dalam konteks bermain yang menyenangkan, hingga situasi kedisiplinan dan tanggung jawab yang kadang dirasakan begitu mengikat atau dengan kata lain bermain sambil belajar. Selain itu dengan adanya pendekatan bermain akan semakin memperjelas dan menambah motivasi untuk terus berlatih passing bawah.

\section{Simpulan}

Berdasarkan hasil penelitian, maka peneliti dapat menyimpulkan bahwa pembelajaran passing bawah menggunakan metode bermain dapat meningkatkan hasil belajar siswa kelas V SD Negeri Pandan 1 Kecamatan Omben Kabupaten Sampang. Penggunaan metode bermain ini dapat digunakan sebagai suatu alternative dalam 
melaksanakan proses pembelajaran pendidikan jasmani khususnya yang berkaitan dengan peningkatan hasil belajar passing bawah bola voli, serta menarik siswa untuk lebih aktif dan menghilangkan anggapan siswa bahwa permainan bola voli itu monoton, menyakitkan dan kadang kurang diminati siswa.

\section{Daftar Rujukan}

Barth, Katrin ; Heuchert, R. (2007). Learning Volleyball. New York: Mayer \& Mayer Sport.

Hanif;, \& Sugito. (2015). Membentuk Gerak Dasar Pada Siswa Sekolah Dasar Melalui Permainan Tradisional. Jurnal SPORTIF : Jurnal Penelitian Pembelajaran, 1(1), 100-113. Pambudi, P. S., \& Pramudana, J. (2016). Penerapan Pembelajaran Drill dan Bermain Terhadap Hasil Belajar Servis Bawah Dalam Permainan Bola voli Pada Siswa Kelas VII SMPN 2 Banyuwangi. Jurnal SPORTIF : Jurnal Penelitian Pembelajaran, 2(2).

Tedjasaputra. (2001). Bermain, Main dan permainan untuk usia dini. Jakarta: Grasindo.

Viera, B. L. (2000). Bola Voli (Tingkat Pemula) diterjemahkan oleh Monti. Jakarta: Raja Grafindo Persada. 